\title{
EFFECTS OF AGROECOLOGICAL CONDITIONS AND HYBRID COMBINATIONS ON MAIZE SEED GERMINATION
}

\author{
M. Tabaković ${ }^{*}$, Đ. Glamočlija ${ }^{2}$, S. Jovanović ${ }^{1}$, V. Popović ${ }^{3}$, D. Simić ${ }^{4}$, \\ S. Anđelković 5
}

${ }^{1}$ Maize Research Institute, Slobodana Bajica 1, Zemun Polje, Serbia
${ }^{2}$ Faculty of Agriculture, University of Belgrade, Nemanjina 6, Zemun, Serbia
${ }^{3}$ Institute of Field and Vegetable Crops, Maxim Gorky 30, Novi Sad, Serbia
${ }^{4}$ Institute of PKB Agroeconomic, Padinska Skela, Belgrade, Serbia
${ }^{5}$ Delta Agrar, Milentija Popovica 7 b, 11070 Belgrade, Serbia
${ }^{*}$ Corresponding author: E-mail address: mtabakovic@mrizp.rs
Original scientific paper

Abstract: Germination energy and seed germination of four maize combinations cultivated under different growing conditions were observed. Analysis of hybrid seed of four commercial combinations derived at the Maize Research Institute, Zemun Polje, grown in three locations, were done on the working sample of $4 \times 100$ seeds under laboratory conditions. The experimental data was processed for the mean and total variability ( $\overline{\mathrm{X}}$ and C.V.) for both seed traits and for each test variant. The total average values of germination energy and germination in the period of investigation amounted to $94.5 \%$ and $94.8 \%$, respectively. The coefficient of variation for germination energy was $0.67 \%$, while for germination it was $0.39 \%$. In the five-year study, the hybrid combination ZP704 had the highest values of germination energy (95.9\%) and total germination (96.3\%).Test results indicate that coefficients of variations for both observed traits over years were low, which points out to homogeneity of the material. Significant effects of factors (hybrid and location) and their interaction on observed seed properties were established by the analysis of variance. Gained results indicate that all four hybrids had high level of expression of traits under changeable agroecological conditions, as well as, a great effect of factors (hybrid and location) on germination energy and seed germination.

Key words: maize, hybrid seed, fraction, location, germination energy, germination 


\section{Introduction}

A necessary and appropriate number and arrangement of plants in the hybrid maize commercial crop can be primarily provided by sowing seeds of good physiological-physical and mechanical properties.

From the scientific, research and technological point of view, germination is a physiological trait of hybrid maize seed that depends on embryo viability and environmental conditions under which this process occurs. Seed germination is a complex, biochemical, physiological and morphological process and is a first critical moment in the formation of a new plant. According to Ujević and Kovačević (1972), the germination process proceeds in three stages, starting with the enzyme activation, continues through degradation of reserve materials and translocation and mobilisation of soluble substances as well as reactions that provide the growth. Studies carried out by McDonald et al., (1994) show that the most active water uptake by maize seeds occurs during the first six hours of seed imbibition and that it is more pronounced in the embryo than in the endosperm. Physical and mechanical seed traits depend on agro-ecological conditions during the seed formation and maturation. Physiological traits of maize hybrid seed also depend on agro-ecological conditions (Fenner and Thompson, 2005). According to studies performed by Shien and McDonald, (1982) the seed size and shape of two maize inbred lines did not affect see quality. Based on results presented by Chasso (2000) and Maric at al. (2013) temperatures of both, surface layers of the soil and air, are the main physiological stress factor of the early growth of the maize plant in the no-tillage growing system. Stone et al. (1999) have established that the soil temperature directly affected meristem tissues of roots and shoots.

All traits of hybrid seeds of maize also depend on a genotypic combination and an interaction of the combination with agro-ecological conditions during the growing season of seed crops. Lee et al. (2002) have determined significant differences in tolerance to low temperatures related to a genotype, and these differences affected the growth dynamics of roots and above ground plant organs. Genetic traits of a hybrid combination, as stated by Sikder et al. (2009), have a great effect on seed germination.

The issue that arises in commercial hybrid maize growing practices is how to harmonise traits of seeds originating from different combinations and produced under various agro-ecological conditions. Success in resolving this issue will be reflected in the optimal utilisation of heterosis effects that are involved in a hybrid combination or a genotypic constitution of hybrid maize seed.

The research programme encompassed experimental studies of traits of hybrid seeds of the F1 generation, mathematical-statistical processing, evaluation and the analysis of obtained data. 


\section{Materials and Methods}

The seed of hybrid combinations ZP 341, ZP 434, ZP 684 and ZP 704 produced in the following three locations in Bačka: surroundings of Subotica (northern Bačka - B 1), surroundings of Novi Sad (southern Bačka - B 2) and surroundings of Sombor (western Bačka - B 3) was used as a material in the present study. Trials in all locations were carried out on chernozem type of soil, which, by its physical and mechanical properties, met requirements of maize production.

Standard cropping practices for seed maize production were applied in all three locations. The establishment of macro-trials for each hybrid combination was done according to standards prescribed by the Regulation on control of the seed production, the content and the method of keeping records on production of seedlings of agricultural crops and the form on the report on the production of mycelia of edible and medicinal fungi (Official Gazette of RS, issue 60/2006). The distribution of precipitation and heat was observed over pheno-phases during the growing season of seed maize. Data on meteorological conditions were recorded in hydrometeorological stations closest to trial fields. Weather conditions significantly varied over years and locations during the five-year period of investigation.

Working samples of $1000 \mathrm{~g}$, obtained from natural seed material of 25-30 $\mathrm{kg}$, were used to perform the analysis of germination energy and seed germination, by methods of Regulation on Seed Testing Quality of Agricultural Crops (Official Gazette 47/87) and (ISTA, 1996) in the following manner: working sample of $4 \times 100$ seeds was used under the standard temperature and between paper $\left(\mathrm{t}=20 / 30^{\circ} \mathrm{C}\right.$, under $16 / 8 \mathrm{~h}$ light/dark conditions), germination energy - 4 days, germination seed -7 days.

Gained experimental data were processed by the appropriate mathematicalstatistical methods using the statistical software package STATISTICA 10.0 for Windows.

Each of obtained parameters was processed by the statistical analysis using descriptive statistics for each parameter at the annual level (2007-2011). Differences among analysed maize hybrids cultivated in three locations of Bačka were observed by the analysis of variance for the factorial trial set up according to the randomised block design and by the LSD test for the probability levels $5 \%$ and $1 \%$ (Maletić, 2005). Levene's test of homogeneity of variance was used with the aim to reach unbiased conclusions about effects of observed factors on maize seed traits, as well as the possibility to apply parametric tests (ANOVA and LSD-test). 
Agroecological conditions. Data on average temperatures and precipitation sums for the vegetation season in the 2007- 2011 period were processed for each trial location.

According to recorded data on average temperatures, the warmest year was 2010 in the location of B1, with the highest average temperature of $19.5^{\circ} \mathrm{C}$ (Table 1).

The precipitation sums were uniform for the first four years of investigation, ranging from 320 to $470 \mathrm{~mm}$ (Table 2). In 2011, the precipitation sum was significantly higher (above $700 \mathrm{~mm}$ ), with the highest value of $751 \mathrm{~mm}$ in the location of B2.

Water requirements of crops depend on the developmental stage, hence the optimal water regime is determined not only by the total precipitation but also by its distribution. The higher water requirements $(100-150 \mathrm{~mm})$ are in the summer months (June-July). The highest five-year precipitation average was recorded in April, while the maximum precipitation sum $(210 \mathrm{~mm})$ was recorded in the location of $\mathrm{B} 3$ in 2011. The maximum amount of precipitation of $92 \mathrm{~mm}$ was recorded in the location of B1 in 2007.

Table 1 Average air temperatures in locations of Bačka, Serbia, 2007-2011

\begin{tabular}{|c|c|c|c|c|c|c|c|c|c|c|c|c|c|c|c|}
\hline Y & \multicolumn{3}{|c|}{2007} & \multicolumn{3}{|c|}{2008} & \multicolumn{3}{|c|}{2009} & \multicolumn{3}{|c|}{2010} & \multicolumn{3}{|c|}{2011} \\
\hline M & B & B 2 & B 3 & B 1 & B 2 & B 3 & B 1 & B 2 & B 3 & B 1 & B 2 & B 3 & B 1 & B 2 & B 3 \\
\hline IV & 14 & 12 & 12 & 14 & 13 & 13 & 13 & 13 & 12 & 14 & 14 & 14 & 11 & 12 & 12 \\
\hline V & 17 & 16 & 16 & 18 & 18 & 18 & 18 & 18 & 18 & 19 & 18 & 18 & 17 & 17 & 16 \\
\hline VI & 20 & 19 & 20 & 23 & 22 & 22 & 22 & 21 & 21 & 20 & 19 & 19 & 20 & 20 & 20 \\
\hline VII & 25 & 23 & 23 & 25 & 23 & 23 & 22 & 21 & 21 & 24 & 22 & 23 & 21 & 23 & 22 \\
\hline VII & 20 & 19 & 19 & 23 & 22 & 22 & 23 & 22 & 21 & 24 & 23 & 22 & 21 & 21 & 21 \\
\hline IX & 19 & 18 & 17 & 14 & 14 & 14 & 16 & 15 & 15 & 20 & 19 & 18 & 16 & 16 & 15 \\
\hline X & 14 & 13 & 12 & 10 & 10 & 10 & 13 & 13 & 12 & 13 & 11 & 11 & 11 & 9 & 8 \\
\hline A & 18 & 17 & 18 & 18 & 17 & 18 & 18 & 18 & 18 & 19 & 18 & 18 & 17 & 17 & 17 \\
\hline
\end{tabular}

Y- Years, M- Month, A- Average, B 1- northern Bačka, B 2- southern Bačka, B 3- western Bačka

Table 2 Monthly precipitation sums in locations of Bačka, Serbia, 2007-2011

\begin{tabular}{|c|c|c|c|c|c|c|c|c|c|c|c|c|c|c|c|}
\hline Y & \multicolumn{3}{|c|}{2007} & \multicolumn{3}{|c|}{2008} & \multicolumn{3}{|c|}{2009} & \multicolumn{3}{|c|}{2010} & \multicolumn{3}{|c|}{2011} \\
\hline M & B 1 & B 2 & B 3 & B 1 & B 2 & B 3 & B 1 & B 2 & B 3 & B 1 & B 2 & B 3 & B 1 & B 2 & B 3 \\
\hline V & 92 & 66 & 88 & 1 & 0 & 1 & 23 & 22 & 41 & 27 & 4 & 14 & 90 & 64 & 54 \\
\hline V & 50 & 70 & 51 & 171 & 99 & 69 & 42 & 15 & 21 & 78 & 50 & 53 & 160 & 114 & 93 \\
\hline VI & 135 & 104 & 147 & 39 & 71 & 87 & 124 & 116 & 113 & 104 & 127 & 109 & 174 & 172 & 210 \\
\hline VII & 12 & 61 & 18 & 24 & 39 & 44 & 60 & 42 & 48 & 74 & 58 & 29 & 53 & 99 & 107 \\
\hline VII & 98 & 125 & 115 & 53 & 80 & 57 & 25 & 14 & 21 & 35 & 19 & 50 & 47 & 169 & 49 \\
\hline IX & 13 & 24 & 8 & 52 & 79 & 96 & 77 & 94 & 64 & 38 & 13 & 2 & 122 & 68 & 129 \\
\hline X & 23 & 18 & 17 & 88 & 101 & 101 & 38 & 18 & 22 & 53 & 82 & 71 & 62 & 67 & 59 \\
\hline S & 422 & 467 & 444 & 428 & 469 & 453 & 388 & 351 & 330 & 409 & 353 & 327 & 707 & 751 & 701 \\
\hline
\end{tabular}

Y- Years, M- Month, S-Summ, B 1- northern Bačka, B 2- southern Bačka, B 3- western Bačka 


\section{Results and Discussions}

Laboratory tests, as well as results obtained in the field, confirm that germination and germination energy of maize seeds are higher at higher temperatures (Sabovljević et al,. 2011; Rosić, 1959; Stikić, 2005; Pinnel, 1949). According to Chassot (2000), the mean daily air temperature necessary for successful maize cultivation should be $8-10 \mathrm{oC}$ and $10-12^{\circ} \mathrm{C}$ in the stage of germination and the stage of emergence, respectively. Temperature conditions were uniform over locations, while the precipitation distribution was satisfactory over locations and years. Maize tolerance to extreme conditions is genetically predetermined, limiting values for the photosynthetic activity amount to $15 \mathrm{oC}$ in the majority of genotypes (Lee et al., 2002).

The five-year average seed germination and germination energy of all observed hybrids was above $90 \%$ (Table 3 ). The total average values of germination energy and germination in the period of investigation amounted to $94.5 \%$ and $94.8 \%$, respectively (Table 3 ). The coefficient of variation for germination energy and germination was $0.67 \%$ and $0.39 \%$, respectively. In the five-year study, the hybrid combination ZP704 had the highest values of germination energy $(95.9 \%)$ and total germination $(96.3 \%)$. This hybrid was followed by the hybrid ZP684 with germination energy of $94.8 \%$ and germination of $95.4 \%$. The hybrid ZP434 ranked third and last considering germination energy and germination, respectively. Furthermore, the hybrid ZP341 had the lowest germination energy, while it was just behind ZP684 considering germination. Based on the evaluation of locations, the mean germination energy and. germination for all hybrids in the observed period were determined in the location $\mathrm{B} 3$ and $\mathrm{B} 2$, respectively.

The coefficient of variation was low $(1 \%<\mathrm{x}<7 \%)$ pointing out to material homogeneity and the insignificant effect of locations. 
Table 3 Means and variations in traits germination energy and seed germination

\begin{tabular}{|c|c|c|c|c|c|c|c|c|c|c|c|}
\hline \multirow[t]{2}{*}{ Year } & \multirow[t]{2}{*}{ Location } & \multicolumn{4}{|c|}{ Energy } & \multirow{2}{*}{$\begin{array}{c}\text { Mean } \\
\text { ek }\end{array}$} & \multicolumn{3}{|c|}{ Germination } & \multicolumn{2}{|c|}{ Mean } \\
\hline & & ZP341 & ZP434 & ZP684 & ZP704 & & ZP341 & ZP434 & ZP684 & ZP704 & $\mathrm{uk}$ \\
\hline \multirow{5}{*}{2007} & B 1 & 97.8 & 93.8 & 93.4 & 94.8 & 94.9 & 97.8 & 93.8 & 93.4 & 96.2 & 95.3 \\
\hline & B 2 & 96.8 & 95.8 & 93.8 & 95.8 & 95.5 & 98.8 & 95.8 & 93.8 & 95.8 & 96.0 \\
\hline & B 3 & 96.2 & 98.2 & 94.6 & 95.4 & 96.1 & 96.2 & 98.2 & 94.6 & 95.4 & 96.1 \\
\hline & Average & 96.9 & 95.9 & 93.9 & 95.3 & 95.5 & 97.6 & 95.9 & 93.9 & 95.8 & 95.8 \\
\hline & $\mathrm{CV}$ & 1.18 & 2.32 & 2.83 & 4.70 & 0.72 & 1.18 & 2.32 & 2.83 & 4.70 & 0.74 \\
\hline \multirow{5}{*}{2008} & B 1 & 82.5 & 95.6 & 94.0 & 98.2 & 92.5 & 94.0 & 95.6 & 97.0 & 98.2 & 96.2 \\
\hline & B 2 & 98.0 & 90.1 & 94.0 & 98.8 & 95.2 & 98.0 & 90.1 & 95.0 & 98.8 & 95.4 \\
\hline & B 3 & 92.6 & 95.2 & 96.0 & 98.8 & 95.6 & 93.2 & 95.2 & 96.0 & 98.8 & 95.8 \\
\hline & Average & 91.0 & 93.6 & 94.6 & 98.6 & 94.43 & 95.0 & 93.6 & 96.0 & 98.6 & 95.8 \\
\hline & $\mathrm{CV}$ & 6.19 & 2.92 & 2.45 & 1.19 & 5.69 & 5.57 & 2.31 & 2.01 & 1.19 & 0.32 \\
\hline \multirow{5}{*}{2009} & B 1 & 93.1 & 97.2 & 94.4 & 89.6 & 93.5 & 93.9 & 97.2 & 94.4 & 89.8 & 93.8 \\
\hline & B 2 & 82.6 & 98.2 & 95.0 & 97.8 & 93.4 & 95.8 & 98.2 & 95.0 & 97.8 & 96.7 \\
\hline & B 3 & 96.4 & 96.0 & 94.4 & 92.8 & 94.9 & 83.4 & 96.0 & 96.2 & 95.0 & 92.6 \\
\hline & Average & 90.7 & 97.1 & 94.6 & 93.4 & 93.93 & 91.0 & 97.1 & 95.2 & 94.2 & 94.4 \\
\hline & $\mathrm{CV}$ & 6.59 & 2.16 & 1.90 & 4.72 & 1.41 & 5.08 & 1.85 & 1.71 & 3.38 & 8.89 \\
\hline \multirow{5}{*}{2010} & B 1 & 91.2 & 91.4 & 95.4 & 96.6 & 93.6 & 92.5 & 91.4 & 96.2 & 98.0 & 94.5 \\
\hline & B 2 & 92.2 & 92.0 & 97.8 & 98.2 & 95.0 & 92.2 & 92.0 & 98.6 & 98.2 & 95.2 \\
\hline & B 3 & 96.4 & 91.6 & 96.4 & 93.8 & 94.5 & 96.6 & 91.6 & 96.4 & 94.2 & 94.7 \\
\hline & Average & 93.2 & 91.6 & 96.5 & 96.2 & 94.4 & 93.7 & 91.6 & 97.0 & 96.8 & 94.8 \\
\hline & $\mathrm{CV}$ & 3.01 & 2.84 & 2.16 & 2.78 & 1.01 & 2.67 & 2.22 & 1.73 & 2.17 & 0.26 \\
\hline \multirow{5}{*}{2011} & B 1 & 95.8 & 90.8 & 95.2 & 96.2 & 94.5 & 95.8 & 90.8 & 95.2 & 96.2 & 94.5 \\
\hline & B 2 & 96.0 & 93.0 & 93.6 & 96.0 & 94.6 & 96.0 & 93.0 & 93.6 & 96.0 & 94.6 \\
\hline & B 3 & 96.0 & 92.0 & 94.8 & 95.2 & 94.5 & 96.0 & 92.0 & 95.8 & 95.8 & 94.9 \\
\hline & Average & 95.9 & 91.9 & 94.5 & 95.8 & 94.5 & 95.9 & 91.9 & 94.8 & 96.0 & 94.7 \\
\hline & $\mathrm{CV}$ & 1.34 & 2.69 & 1.59 & 1.62 & 0.01 & 1.34 & 2.48 & 1.76 & 1.66 & 0.09 \\
\hline \multirow{5}{*}{$\begin{array}{l}2007 \\
- \\
2011 \\
\end{array}$} & B 1 & 92.1 & 93.8 & 94.5 & 95.1 & 93.9 & 94.8 & 93.8 & 95.2 & 95.7 & 94.3 \\
\hline & B 2 & 93.8 & 93.8 & 94.5 & 97.3 & 94.8 & 96.2 & 93.8 & 95.2 & 97.3 & 95.2 \\
\hline & B 3 & 94.6 & 94.6 & 95.2 & 95.2 & 94.9 & 93.1 & 94.6 & 95.8 & 95.8 & 94.9 \\
\hline & Average & 93.6 & 94.1 & 94.8 & 95.9 & 94.5 & 94.7 & 94.1 & 95.4 & 96.3 & 94.8 \\
\hline & $\mathrm{CV}$ & 3.26 & 0.43 & 0.33 & 3.09 & 0.67 & 4.82 & 0.43 & 0.24 & 1.61 & 0.39 \\
\hline
\end{tabular}

B 1- northern Bačka, B 2- southern Bačka, B 3- western Bačka

In order to apply tests and parametric tests, homogeneity of variance of selected samples was checked by Levene's test (Table 4). Obtained results indicate that samples were not uniform for both properties $(\mathrm{F}=4.1093, \mathrm{p}=0.00 ; \mathrm{F}=4.3618$, $\mathrm{p}=0.00)$ in 2007 and for germination energy $(\mathrm{F}=3.3463, \mathrm{p}=0.0001)$ in 2008 and therefore in the process of testing these results the level of significance has to more rigorous, i.e. $1 \%$. 
Table 4 Levene`s test

\begin{tabular}{|c|l|c|c|}
\hline \multicolumn{1}{|l|}{ Yers } & \multicolumn{1}{|c|}{ Test } & Energy & Germination \\
\hline \multirow{2}{*}{2007} & F & 4.1093 & 4.3618 \\
\cline { 2 - 4 } & p-level & 0.0000 & 0.0000 \\
\hline \multirow{2}{*}{2008} & F & 3.3463 & 1.6485 \\
\cline { 2 - 4 } & p-level & 0.0001 & 0.0643 \\
\hline \multirow{2}{*}{2009} & F & 2.8835 & 2.8330 \\
\cline { 2 - 4 } & p-level & 0.0005 & 0.0006 \\
\hline \multirow{2}{*}{2010} & F & 2.8417 & 2.8440 \\
\cline { 2 - 4 } & p-level & 0.052 & 0.053 \\
\hline \multirow{2}{*}{2011} & F & 1.5481 & 2.9763 \\
\cline { 2 - 4 } & p-level & 0.052 & 0.0589 \\
\hline
\end{tabular}

Effects of factors on germination energy and seed germination were determined by the two-factorial analysis of variance (Table 5). The difference in seed germination energy as well as in seed germination was significant over all hybrids in all five years of production. The location, as a second factor, had no statistical significance for neither of observed properties in $2007(\mathrm{~F}=1.09, \mathrm{~F}=1.89)$ nor for just germination energy in $2009(\mathrm{~F}=1.73)$. The effect of the interaction of the two factors was observed in the five-year production. The values of $F$ test in all tests point out that the hybrid combination $\mathrm{x}$ location interaction is of great significance for differences occurred in seed germination energy and seed germination.

Table 5 Statistical significance of differences in germination energy and seed germination (F and LSD test)

\begin{tabular}{|c|c|c|c|c|c|c|c|}
\hline Yers & Test & \multicolumn{3}{|c|}{ Energy } & \multicolumn{3}{|c|}{ Germination } \\
\hline & & $\mathrm{H}$ & $\mathrm{L}$ & I & $\mathrm{H}$ & $\mathrm{L}$ & I \\
\hline \multirow{3}{*}{2007} & F-test & $6.68 * *$ & 1.09 & $2.47 * *$ & $8.59 * *$ & 1.89 & 3.09 \\
\hline & LSD 0.01 & 1.456 & 1.629 & 3.256 & 0.976 & 1.091 & 2.182 \\
\hline & LSD 0.05 & 1.917 & 2.146 & 4.286 & 1.185 & 1.236 & 2.873 \\
\hline \multirow{3}{*}{2008} & F-test & $43.38^{* *}$ & $16.01 * *$ & $26.49 * *$ & $46.29 * *$ & $12.17 * *$ & $27.08 * *$ \\
\hline & LSD 0.01 & 0.876 & 0.980 & 1.960 & 0.784 & 0.876 & 1.756 \\
\hline & LSD 0.05 & 1.154 & 1.290 & 2.580 & 1.032 & 1.154 & 2.308 \\
\hline \multirow{3}{*}{2009} & F-test & $23.67 * *$ & 1.73 & $5.43 * *$ & $46.59 * *$ & 17.31 ** & $17.49 * *$ \\
\hline & LSD 0.01 & 1.735 & 1.940 & 3.881 & 0.876 & 0.980 & 1.960 \\
\hline & LSD 0.05 & 2.284 & 2.554 & 5.108 & 1.154 & 1.290 & 2.580 \\
\hline \multirow{3}{*}{2010} & F-test & $16.9 * *$ & $6.98^{* *}$ & $4.69 * *$ & $23.67 * *$ & $6.38^{* *}$ & $8.07^{* *}$ \\
\hline & LSD 0.01 & 1.095 & 1.224 & 2.448 & 0.803 & 0.898 & 1.796 \\
\hline & LSD 0.05 & 1.441 & 1.611 & 3.222 & 1.057 & 1.182 & 2.365 \\
\hline \multirow{3}{*}{2011} & F-test & $18.68^{* *}$ & $5.77 * *$ & $3.97 * *$ & $11.39 * *$ & $5.27 * *$ & $4.09 * *$ \\
\hline & LSD 0.01 & 0.784 & 0.877 & 1.753 & 0.784 & 0.876 & 1.753 \\
\hline & LSD 0.05 & 1.032 & 1.541 & 2.308 & 1.032 & 1.154 & 2.308 \\
\hline
\end{tabular}

H-hybrid, L-location, I-interaction 
Effects of factors on germination energy and seed germination were determined by the two-factorial analysis of variance (Table 5). Observed factors did not have only statistically significant effect on germination energy and seed germination, but also had a very high partial eta-squared value. To which extent will certain factors affect expressing of particular traits depends on the duration of their action (Rakić et al., 2012). Therefore, both factors, as well as their interaction, had a great effect on changes in germination energy and seed germination. It has been determined that many factors affected the process of maize seed germination, individually but also in the interactions, but gained results referred to seed as a whole (Sabovljević et al., 2011). Stress agroecological conditions, such as drought, are some of factors affecting morphological and physiological traits of seed (Camacho et al., 1994). According to data obtained by Walles and Bressman (cit. Glamočlija, 2012), the amount of precipitation necessary to achieve the grain yield of $6.35 \mathrm{t}$ ha- 1 is $480-600 \mathrm{~mm}$. Germination and emergence are stages which cannot start without water, hence the minimum soil moisture necessary for seed germination amounts to $305 \mathrm{~g} / \mathrm{kg}$, (Hunter and Erickson, 1952). According to (Mayer and Poljakoff-Mayber, 1982) the amount of absorbed water depends on colloid properties.

In 2007 and 2009, agro-ecological conditions did not statistically significantly affect these traits. The highest partial eta-squared values for germination energy of both factors $(\eta 2=0.6196, \eta 2=0.4447)$ were recorded in 2008. Furthermore, the interactions of factors in 2007 significantly contributed to the differences in germination energy of observed hybrids $(\eta 2=0.79992)$. The highest partial effect of the hybrid combinations as well as of the interaction of factors on the differences in seed germination was recorded in $2008(\eta 2=0.6343$ and $\eta 2=0.8024$, respectively), while in 2009 , the location had the highest partial effect $(\eta 2=04639)$.

\section{Conclusion}

Based on studies about effects of agro-ecological conditions and hybrid combinations on germination energy and total germination the following can be concluded that effects of observed factors on the trait expression of maize hybrid seed differ in their extent and modes - they can be immediate and direct, more or less indirect, they can occur through greater or smaller interactions and in a modified mode. Means and variations in traits of maize hybrid seed are of complex nature and are a resultant of effects of all stated factors and all stated ways of their actions. Results obtained by the analysis of variance, F-test values and probabilities of these values indicate that the effect of certain factors on the expression of observed seed traits is not equal for all hybrid combinations. Results obtained by the analysis of effects of factors on the trait expression of maize hybrid seeds show 
the major significance of a genotypic or a hybrid combination of these seeds, i.e. of plant traits, as well as of flowering congruence of parental inbreeds in the seed crop.

\title{
Acknowledgement
}

This work is part of project number TR-31006, financed by Ministry of Education, Science and Technological Development of the Republic of Serbia.

\section{Uticaj agroekoloških uslova i hibridne kombinacije na klijavost semena kukuruza}

\author{
M. Tabaković, Đ. Glamočlija, S. Jovanović, V. Popović, S. Anđelović
}

\section{Rezime}

U ovim istraživanja proučavane su energija klijanja i klijavost semena kukuruza četiri genotipske kombinacije u različitim agroekološkim uslovima uspevanja. Analize hirbidnog semena četiri komercijalne kombinacije Instituta za kukuruz Zemun Polje, proizvedene na tri lokaliteta, urađene su u laboratorijskim uslovima na radnom uzorku 4 x 100 semena. Eksperimentalni podaci obrađeni su na srednju vrednost i ukupnu varijabilnost ( $\bar{X}$ i C.V.) za obe osobine semena $i$ svaku varijantu istraživanja.

Ukupna prosečna vrednost energije klijanja u posmatranom periodu bila je $94.5 \%$, a klijavost $94.8 \%$. Koeficijent varijacije za energiju iznosio je $0.67 \%$, a za klijavost $0.39 \%$. Hibridna kombinacija ZP704 u petogodišnjim istraživanjima imala je najviši nivo energije klijanja (95.9\%) i ukupne klijavosti (96.3\%). Rezultati testova ukazuju da koeficijenti varijacije ispitivanih karakteristika kod obe osobine su mali i ukazuju na homogenost materijala. Dvofaktorijalnom analizom varijanse utvrđen je značajan uticaj faktora (hibrid i lokacija), kao i njihova interakcija na ispitivane osobine semena.

Dobijeni rezultati pokazali su da sva četiri hibrida imaju visok nivo ispoljavanja ispitivanih osobina $u$ promenljivim agroekološkim uslovima, kao i visok uticaj faktora ( hibrid i lokalitet) na energiju i klijavost semena. 


\section{References}

BEKAVAC G., PURAR B., JOCKOVIC DJ. (2008): Relationships between line per se and testcross performance for agronomic traits in two broad-based populations of maize (Article), EUPHYTICA, 162, 3, 363-369

CAMACHO, R.G. AND CARABALLO D.F. (1994): Evaluation of morphological characteristics in Venezuelan maize (Zea mays L.) genotypes under drought stress. Science of Agriculture (Piracicaba, Braz.). 51 (3), 453-458

CHASSOT A. (2000): Early growth of roots and shoots of maize as affected by tillage-induced changes in soil physical properties. Zurich. Diss. ETH No. 13907

FENNER, M. AND THOMPSON M. (2005): The ecology of seeds. Cambridge University, UK.

GLAMOCLIJA, Dj. (2012): Especially farming, grain legumes and grains (corn), Faculty of Agriculture, Belgrade, 122-176.

HUNTER, J.R. AND ERICKSON A.E. (1952): Relation of seed germination to soil moisture tension. Agronomy Journal 44, 107-109.

ISTA 1996. ISTA handbook on seed sampling. International Seed Testing association. Zurich, Switzerland.

LEE, E.A., STAEBLER M.A., TOLLENAAR M. (2002): Genetic variation and physiological discrimination for cold tolerance in maize (Zea Mays L.) during an early autotrophic phase of development. Crop Sci. 42, 1919-1929

MALETIĆ R., (2005): Statistics. Faculty of Agriculture, Belgrade,

MARIC V., GLAMOCLIJA DJ., POPOVIC V., DJUKANOVIC L. (2013): Maize hybrids from different maturity groups over sowing densities. Institute of PKB Agroekonomik, Padinska Skela, Belgrade, 19, 1-2, 117-124

MAYER A.M. AND A. POLJKOFF-MAYBER (1982): The germination of Seeds. Third edition, Pergamon Press, Great Britain

McDONALD M.B., SULLIVAN J., LAVER M.J. (1994): The pathway of water uptake in maize seeds. Seed Science and Technology, 22, 79-90.

PINNEL E. L. (1949): Genetic and environmental factors affecting seed corn germination at low temperature; J. Am. Loc. Agron., 41, 562-568.

RAKIĆ S., JANKOVIĆ S., KRIVOKAPIĆ M., JOVANOVIĆ R., IKANOVIĆ J. (2012): Grain quality and status of Oats (Avena sativa L.) during storage. Biotechnology in Animal Husbandry 28 (4), 863-871.

ROSIC K. (1959): The influence of certain fractions of the seeds develop, the growth and yield of maize. Hybrid corn Yugoslavia, 9, 3-17.

SABOVLJEVIĆ R., SIMIĆ D., MILOSAVLJEVIĆ S., ACIMOVIĆ B., GORANOVIĆ DJ., SELAKOVIĆ D. (2011): Effect calibration properties of hybrid seed corn, Institute of PKB Agroekonomik, Belgrade, vol. 17. No. 1-2, 81100 . 
SHIEN W.J. AND McDONALD B.M. (1982): The influence of seed size, shape and treatment on inbred seed corn quality. Seed Sci Techno., 10, 307-313.

SIKDER S., HASAN M.A. AND HOSSAIN M.S. (2009): Germination Characteristics and Mobilization of Seed Reserves in Maize Varieties as Influenced by Temperature Regimes. Journal of Agriculture and Rural Development, No 7 (1\&2), 51-56

STIKIĆ, R. (2005): Physiology of growth and development of plants, Faculty of Agriculture, University of Belgrade.

STOJAKOVIC, M., JOCKOVIC Dj., BEKAVAC G., PURAR, B. NASTASIC A. (1999): Variability and interrelationships between traits of two maize populations. Acta Agronomica Hungarica, Vol.47, (4), 383-390.

STONE, P. J., SORENSEN I.B, JAMIESON P.D. (1999): Effect of soil temperature on phenology, canopy development, biomass and yield of maize in a cool temperature climate. Field Crop. Res. 63, 169-178.

UJEVIĆ, A.I., KOVACEVIĆ J. (1972), Seed Testing. Department of seeds, Zagreb.

ZIVANOVIC Lj., IKANOVIC J., POPOVIC V., KAJGANA M., RAKIC S., MILUTINOVIC M. (2012): The effect of nitrogen fertilization on yield of maize. „Agrosym Jahorina“, 215-219.

*OFFICIAL GAZETTE OF RS, issue 60/2006: Regulation on control of the seed production, the content and the method of keeping records on production of seedlings of agricultural crops and the form on the report on the production of mycelia of edible and medicinal fungi.

* OFFICIAL GAZETTE OF RS, issue 47/87: Regulation on the quality of seeds of agricultural plants 